Hancock, R. (1957). J. gen. Microbiol. 17, 480-490

\title{
Protein Synthesis in a Species of Thermophilic Bacillus
}

\author{
By R. HANCOCK \\ Medical Research Council Unit for Chemical Microbiology, \\ Department of Biochemistry, University of Cambridge
}

SUMMARY: Washed suspensions of a newly isolated species of thermophilic bacillus were used to investigate the conditions necessary for protein synthesis, and the effect of temperature on the rate of such synthesis. The maximum rate of incorporation of radioactive glycine into the cell protein occurred in the presence of a complete amino acid mixture and an energy source; a mixture of purines and pyrimidines was markedly stimulatory. These conditions were optimal also for the synthesis of catalase and of the maltozymase enzyme-complex, and were effective in preventing the loss of $\beta$-galactosidase and catalase activities which occurred when the cells were suspended in buffer at $55^{\circ}$. The synthesis of these enzymes and the incorporation of glycine showed a temperature optimum approximating to that for growth.

The evidence concerning the growth of thermophilic bacteria suggests that at least two mechanisms may be responsible for the ability of these organisms to grow at temperatures at which mesophilic species are rapidly killed. A number of workers have compared the thermal stability of enzymic activities in thermophilic and mesophilic bacteria; Casman \& Rettger (1933) and Edwards \& Rettger (1937) found some correlation between higher maximum growth temperature and increased thermal resistance of oxidative enzymes among organisms of the genus Bacillus; there were, however, numerous exceptions, including some thermophilic strains in which the enzymes studied were no more thermostable than those of the mesophilic group, and in which the 'minimum temperature for enzyme inactivation' was lower than the maximum temperature for growth. Allen (1953) found that the malic dehydrogenase of thermophilic strains of $\boldsymbol{B}$. circulans was more thermostable than that of mesophilic strains; in thermophilic strains of $B$. subtilis this enzyme was no more thermostable than that in mesophilic strains. Rapid inactivation of the catalase and respiratory activities of some thermophilic strains of $B$. subtilis was also found to occur at the optimum growth temperature. In B. stearothermophilus some enzymes possess increased thermal stability not only in intact organisms but also in subcellular fractions (respiratory systems) and in purified preparations (hydrolytic enzymes) (Militzer, Sonderegger, Tuttle \& Georgi, 1950; Militzer, Tuttle \& Georgi, 1951; Militzer \& Tuttle, 1952; Militzer \& Burns, 1954). Thermal stabilization of an enzyme by association with other proteins occurs in the case of an alanine racemase of $B$. terminalis spores; this enzyme is stable at $80^{\circ}$ in whole spores and in cell-free extracts, but completely loses its thermostability when partially purified (Stewart, 1953). Adye \& Koffler (1953) showed that the flagella of certain thermophilic 
Bacillus species were more resistant to destruction by heat than those from two mesophilic species.

Where no increased thermal resistance of enzymes can be found Allen (1950, 1953) has suggested that the ability of thermophilic organisms to maintain a greater rate of replacement of cell material at high temperatures may be a second mechanism involved in thermophilic growth. Consequently the growth of a thermophilic culture would represent a dynamic equilibrium between rate of thermal inactivation and rate of synthesis of cell components. The present paper describes investigations on the protein-synthesizing systems of a thermophilic Bacillus sp. with particular reference to the effects of temperature.

\section{METHODS \\ Organism and media}

The organism used was an aerobic spore-forming Bacillus sp. isolated from soil by screening for a spore-forming species capable of growth at $55^{\circ}$ but not at $37^{\circ}$. The organism, referred to as Bacillus 631 , resembled most closely those of the $B$. sphaericus group in the classification of Allen (1953) and had the temperature/growth-rate characters shown in Fig. 1. The organism was maintained at $55^{\circ}$ and transferred at 2 day intervals on slopes of solid medium $(\mathrm{pH} 7 \cdot 5)$ containing tryptic hydrolysate of casein $(\equiv 3 \%(\mathrm{w} / \mathrm{v})$ casein), $1 \%$ $(\mathrm{w} / \mathrm{v})$ glucose, $\mathbf{0} \cdot \mathbf{1} \%(\mathrm{v} / \mathrm{v})$ Marmite and $3 \%(\mathrm{w} / \mathrm{v})$ agar (Harrington Bros. Ltd.).

\section{Growth and preparation of suspensions}

For the preparation of washed suspensions the organism was grown in a liquid medium $(\mathrm{pH} 7 \cdot 0)$ containing Oxoid brand peptone $(2 \%, \mathrm{w} / \mathrm{v})+$ glucose $(1 \%, \mathrm{w} / \mathrm{v})$, using as inoculum a suspension of organisms washed from a $15 \mathrm{hr}$. slope culture with $0.85 \%(\mathrm{w} / \mathrm{v}) \mathrm{NaCl}$. Peptone medium $(150 \mathrm{ml}$.) in $250 \mathrm{ml}$. round-bottomed flasks was inoculated to give an initial concentration of c. $5 \mathrm{mg}$. dry wt. organism/100 ml. medium. The flasks were shaken for $4 \mathrm{hr}$. in a water bath at $55^{\circ}$, after which time the culture was growing exponentially and the organisms had divided three or four times (preliminary work had indicated that maximum rates of incorporation of $\left[{ }^{14} \mathrm{C}\right]$ glycine and of enzyme formation were obtained with organisms harvested from cultures in the exponential phase of growth). For experiments under anaerobic conditions the flasks were fitted with a stopper and tap and anaerobiosis was established by alternate evacuation and filling with $\mathrm{N}_{2}$; these flasks were also fitted with a side-arm so that growth could be followed by optical density measurements at $4.50 \mathrm{~m} \mu$. using a 'Unicam' spectrophotometer (model 348DG). The organisms were harvested by centrifugation at $2000 \mathrm{~g}$ for $15 \mathrm{~min}$., washed once in $0.85 \%$ $(\mathrm{w} / \mathrm{v}) \mathrm{NaCl}$ and then resuspended in $0.85 \%(\mathrm{w} / \mathrm{v}) \mathrm{NaCl}$ to a concentration equivalent to $10 \mathrm{mg}$. dry wt. organism/ml. This suspension was diluted tenfold in the final incubation mixtures.

The amounts of organism in suspension were determined from optical density measurements using a Hilger 'Spekker' absorptiometer with a neutral 
filter, and a calibration curve prepared for the organism by drying samples of known optical density to constant weight at $105^{\circ}$. Weights of organism are given throughout in terms of dry weights.

\section{Components of the incubation systems}

Amino acid mixture (A) contained the following amino acids at a concentration of $\mathbf{2} \mathrm{mg}$. of the L-isomer $/ \mathrm{ml}$.: L-alanine, L-arginine hydrochloride, L-aspartic acid, L-cysteine, L-glutamic acid, glycine, L-histidine hydrochloride, DL-isoleucine, L-leucine, L-lysine hydrochloride, DL-methionine, DL-phenylalanine, L-proline, DL-serine, DL-threonine, DL-tryptophane, L-tyrosine, L-valine. The solution was adjusted to $\mathrm{pH} \mathbf{7 \cdot 0}$. Amino acid mixture (B) contained all the above amino acids except glycine. Purine-pyrimidine mixture (PP) contained the following compounds in water at $1.0 \mathrm{mg} . / \mathrm{ml}$.: adenine, guanine, xanthine, hypoxanthine, uracil, thymine. To bring these compounds into solution it was necessary to warm the mixture immediately before use. A buffered salts solution (Gale, 1947) was included in all incubation mixtures at a dilution of $1 / 2$.

$\left[\alpha-{ }^{14} \mathrm{C}\right]$ Glycine was obtained from the Radiochemical Centre, Amersham, and was used at a specific activity of $0 \cdot 1 \mu \mathrm{C} / \mu$ mole by dilution with unlabelled glycine. A generally $\left[{ }^{14} \mathrm{C}\right]$-labelled protein hydrolysate was obtained by hydrolysis $\left(6 \mathrm{~N}-\mathrm{HCl}, 16 \mathrm{hr}\right.$., $105^{\circ}$ in sealed tube) of protein from Chlorella vulgaris grown in $\left[{ }^{14} \mathrm{C}\right] \mathrm{O}_{2}$ (from the Radiochemical Centre, Amersham); radioautographs of chromatograms of this material showed activity in positions corresponding to all amino acids, with highest activity in glutamic and aspartic acids.

\section{Incorporation of $\left[{ }^{14} \mathrm{C}\right]$ glycine}

The incorporation experiments were carried out in boiling tubes containing buffered salts solution (final dilution 1/2), amino acid mixture (B) (100 $\mu \mathrm{g}$. of each L-isomer $/ \mathrm{ml}$.), mixture PP (10 $\mu$ g. of each component $/ \mathrm{ml}$.), glucose ( $1 \%$, $\mathrm{w} / \mathrm{v})$ and $\left[{ }^{14} \mathrm{C}\right] \mathrm{glycine}$ at the indicated concentration. Incubation in this system will be referred to as incubation under condition 2 ; in a similar system without amino acid mixture (B) incubation will be referred to as under condition 1. Components, when omitted, were replaced by water. Organisms were added after the tubes had been equilibrated at the required temperature; tubes were stoppered, and, except where incorporation at a number of different temperatures was being compared, were shaken to improve aeration. The protein fraction of the organisms was prepared as follows: a sample from the incubation mixture was pipetted into one-third of the sample volume of $20 \%$ (w/v) trichloroacetic acid (TCA), centrifuged, extracted three times at $90^{\circ}$ for 10 min. with $5 \%$ (w/v) TCA, washed once with $5 \%(w / v)$ TCA containing unlabelled glycine $(0 \cdot 1 \%, \mathrm{w} / \mathrm{v})$ and once with $5 \%(\mathrm{w} / \mathrm{v})$ acetic acid. The pellet was dissolved in $\mathbf{0 . 2} \mathrm{ml}$. of $\mathrm{N}-\mathrm{NH}_{4} \mathrm{OH}$, plated on a polythene planchette $\left(2 \mathrm{~cm} .{ }^{2}\right)$, together with one drop of cetyltrimethylammonium bromide (1 mg./ml.) and dried over $\mathrm{H}_{2} \mathrm{SO}_{4}$ in vacuo for $16 \mathrm{hr}$. The $\left[{ }^{14} \mathrm{C}\right]$ content of the 
dried preparations was determined by the use of an end-window Geiger-Muller tube and scaler in the conventional manner. All samples were plated at less than $1 \mathrm{mg} . / \mathrm{cm} .^{2}$ so that self-absorption was negligible; at least 1000 counts were recorded. Samples of $\left[{ }^{14} \mathrm{C}\right]$ glycine were plated in a similar manner and counted; activities have been expressed in terms of $\mu$ mole glycine incorporated. To locate radioactivity in the protein fraction, samples of labelled protein were hydrolysed, submitted to two-dimensional paper chromatography, and radioautographs prepared, by the methods described by Roberts et al. (1955). To obtain a clear separation of glycine from serine, samples of the hydrolysate were submitted to paper electrophoresis in $\mathbf{0 . 0 5} \mathrm{M}$-carbonate-bicarbonate buffer ( $\mathrm{pH} \mathrm{9.6)} \mathrm{for} 2 \mathrm{hr}$. at 13.5 V./cm. (Davies, R., personal communication); radioautographs were prepared and components identified by reference to marker amino acids run on the same paper. After incorporation of glycine, in the presence and absence of other amino acids, radioactivity was found only in the glycine residues of the protein.

\section{Incubation mixture for formation of enzymes}

The incubation mixture was the same as that used for the incorporation of $\left.{ }^{[14} \mathrm{C}\right]$ glycine except that the complete amino acid mixture (A) was used; other components were added or omitted as described.

\section{Assay of enzyme activities}

Catalase was assayed by the method of Creaser (1956). Catalase activities were so high that samples of the incubation mixture were taken into manometers for assay; none of the components of the incubation mixture had any effect on the assay procedure.

$\beta$-Galactosidase was assayed by the method of Lederberg (1950) with an incubation period of $15 \mathrm{~min}$. during which the rate of release of $o$-nitrophenol was linear. Ultrasonic breakage of organisms resulted in a $20 \%$ increase in the enzyme activity of a suspension of organisms; the ratio of activity of whole organisms : activity of broken organisms did not change in material assayed after incubation under the experimental conditions used.

Maltozymase (defined here as the system responsible for the uptake of $\mathrm{O}_{2}$ in the presence of maltose and a $\mathrm{CO}_{2}$-absorbent) was estimated in Warburg manometers; cups contained: 2.3 ml. 0.067 M-phosphate buffer ( $\mathrm{pH} \mathrm{6.5}$ ), $0.5 \mathrm{ml} .0 .1 \mathrm{M}$-maltose and $0.2 \mathrm{ml} .40 \%(\mathrm{w} / \mathrm{v}) \mathbf{K O H}$ in the centre well; suspensions of organisms in buffer were added from the side-arm. The gas phase was air and gas uptake was followed at $55^{\circ}$. Activities are expressed as $\boldsymbol{Q}_{\mathbf{o}_{2}}$ values and have been corrected for endogenous gas uptake by organisms in absence of maltose. Manometer joints were greased with silicone highvacuum grease (Dow-Corning).

Protein nitrogen was determined by the Kjeldahl method followed by microdistillation (Markham, 1942) and nesslerization (Johnson, 1941). 


\section{RESULTS}

Incorporation of $\left[{ }^{14} \mathrm{C}\right]$ glycine into cell protein

Fig. 2 shows the rate of incorporation of ${ }^{14} \mathrm{C}$ into the protein fraction of organisms incubated at $55^{\circ}$ under different conditions. There was little incorporation in the absence of an energy source; the presence of 17 other amino acids (condition 2) converted the 'plateau' incorporation obtained in their

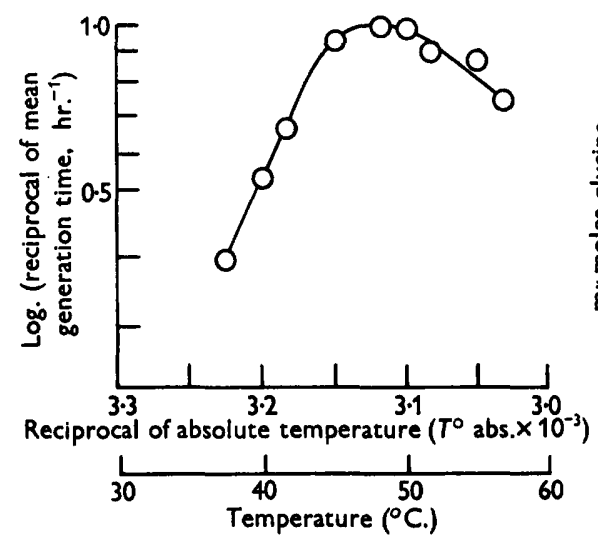

Fig. 1

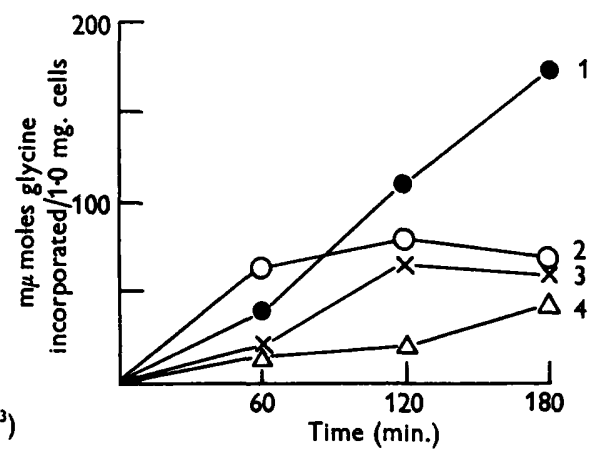

Fig. 2

Fig. 1. Growth rate of Bacillus 631 as a function of temperature. Growth in a medium containing peptone $(2 \%, w / v)$ and glucose $(1 \%, w / v)$ determined by absorption at $450 \mathrm{~m} \mu$ in a 'Unicam' model 348 DG spectrophotometer.

Fig. 2. Incorporation of $\left[{ }^{14} \mathrm{C}\right]$ glycine into the protein fraction of Bacillus 631 . Incubation medium contained buffered salts, 17 amino acids $(100 \mu \mathrm{g} . / \mathrm{ml}$.$) , purine-pyrimidine$ mixture $\left(10 \mu \mathrm{g} . / \mathrm{ml}\right.$.), glucose $(1 \%, \mathrm{w} / \mathrm{v})$ and $\left[{ }^{14} \mathrm{C}\right]$ glycine at $2 \mu \mathrm{mole} / \mathrm{ml}$. (specific activity $0.1 \mu \mathrm{C} / \mu \mathrm{mole}$ ). Curve 1 , complete system; curve 2, amino acids omitted; curve 3 , purine-pyrimidine mixture omitted; curve 4 , glucose omitted. Incubation temperature $55^{\circ}$.

absence (condition 1) into a linear incorporation and under condition 2 a parallel increase in the protein nitrogen of the organisms occurred (Table 1). Under condition 2, different concentrations of glycine gave the results plotted by the method of Lineweaver \& Burk (1934) in Fig. 3. In subsequent

Table 1. Relation between incorporation of $\left[{ }^{14} \mathrm{C}\right]$ glycine and increase in protein in washed suspensions of Bacillus 631.

Incubation medium contained buffered salts, 17 amino acids (100 $\mu \mathrm{g} . / \mathrm{ml}$.), purinepyrimidine mixture $\left(10 \mu \mathrm{g} \cdot / \mathrm{ml}\right.$.), glucose $(1 \%, \mathrm{w} / \mathrm{v})$ and $\left[{ }^{14} \mathrm{C}\right]$ glycine at $2 \mu \mathrm{mole} / \mathrm{ml}$. (specific activity $0 \cdot 1 \mu \mathrm{C} / \mathrm{mole}$ ). Radioactivity and total nitrogen were determined on the protein fraction prepared from $2 \cdot 0 \mathrm{mg}$. cells.

$\begin{array}{ccc}\begin{array}{c}\text { Incubation time } \\ \text { (min.) }\end{array} & \begin{array}{c}\text { Radioactivity } \\ \text { (counts/min.) }\end{array} & \begin{array}{c}\text { Increase in } \\ \text { protein N }(\mu \mathrm{g} .)\end{array} \\ 30 & 910 & 18 \\ 60 & 1640 & 36 \\ 90 & 2000 & 54 \\ 120 & 2660 & 74 \\ 180 & 3810 & 112\end{array}$


experiments a glycine concentration of $2 \mu \mathrm{mole} / \mathrm{ml}$. was used to saturate the incorporation system. The magnitude of the response to an increase in the concentration of mixture PP under condition 2 was variable; in a number of experiments the stimulation of incorporation produced by $10 \mu \mathrm{g}$. mixture $\mathrm{PP} / \mathrm{ml}$. varied from 100 to $300 \%$, and the response was proportional to the concentration of mixture PP (Fig. 4).

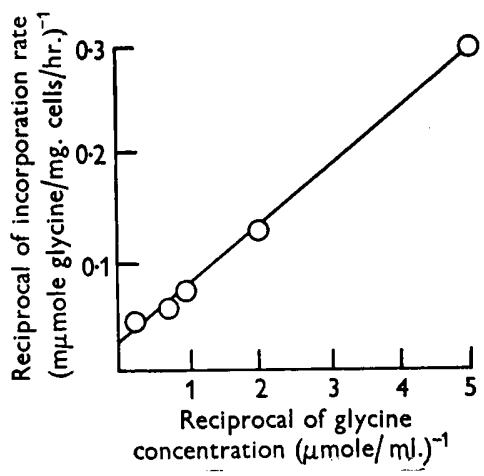

Fig. 3

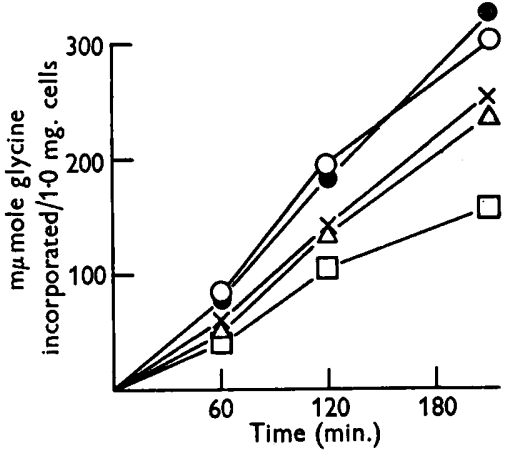

Fig. 4

Fig. 3. Incorporation rate as a function of glycine concentration. Conditions as for Fig. 2, curve 1 , but with concentration of glycine as indicated; incorporation determined after $60 \mathrm{~min}$. at $55^{\circ}$.

Fig. 4. Stimulation of rate of incorporation of $\left[{ }^{14} \mathrm{C}\right]$ glycine into protein fraction by purinepyrimidine mixture. Conditions as for Fig. 2, curve 1, but with concentration of purinepyrimidine mixture $(\mu \mathrm{g} . / \mathrm{ml}$.$) as indicated. (\square, 0 ; \Delta, 2 ; \times, 5 ; 0,10 ; 0,20)$.

\section{The nature of incorporation in absence of other amino acids}

The progress curves of incorporation under conditions 1 and 2 were similar to those obtained for the incorporation of glutamic acid into the protein of Staphylococcus aureus (Gale \& Folkes, 1953a), where it was subsequently shown that in disrupted cell preparations (but not in intact organisms) incorporation under condition 1 was reversible in the presence of unlabelled glutamic acid and an energy source (Gale \& Folkes, 1955). With intact Bacillus 631 attempts to displace $\left[{ }^{14} \mathrm{C}\right]$ glycine, after incorporation, by unlabelled glycine were unsuccessful. It is possible that in this case incorporation under condition 1 was due to synthesis of protein from the amino acids of the internal pool; the size of this pool has been investigated by the ninhydrin method (Cocking \& Yemm, 1954) and at the time of harvesting is c. $0.2 \mu$ mole amino acid/mg. dry wt. organism. Two-dimensional chromatograms of the components of this internal pool showed ninhydrin-reacting spots corresponding to all amino acids except histidine; there was no change in the pattern of distribution after hydrolysis. Synthesis of protein from this pool might result in the incorporation of the observed amount of glycine, c. $0.08 \mu \mathrm{mole} / \mathrm{mg}$. dry wt. organism (Fig. 2). The sensitivity of incorporation to inhibition by $p$-fluorophenylalanine (PFP) differed under conditions 1 and 2. 
After $2 \mathrm{hr}$. in the presence of PFP ( $5 \mathrm{mg} . / \mathrm{ml}$.), under condition 1 incorporation was $28.3 \%$ of control (724 counts/min.) and under condition $2,14.5 \%$ of control (3619 counts/min.). In Staphylococcus aureus incorporation of glutamic acid under condition 1 showed less sensitivity to inhibition by $p$-chlorophenylalanine than did incorporation under condition 2 (Gale \& Folkes, 1953b).

\section{Effect of temperature on rate of incorporation}

Under condition 2 the rate of incorporation of glycine over the range $30^{\circ}-60^{\circ}$ varied as shown in Fig. 5. Between $25^{\circ}$ and $55^{\circ}$ the temperature coefficient of incorporation was $\mathbf{2 \cdot 3}$ (compared with a value from Fig. 1 of $2 \cdot 8$ for growth of the organism). The optimum temperature was higher than that $\left(44^{\circ}\right)$ for the incorporation of glutamic acid in Staphylococcus aureus (Gale $\&$ Folkes, 1953a).

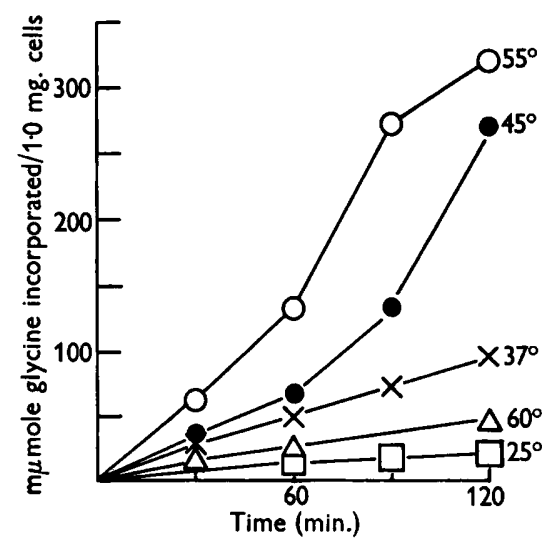

Purines and pyrimidines

Chloramphenicol

Fig. 5

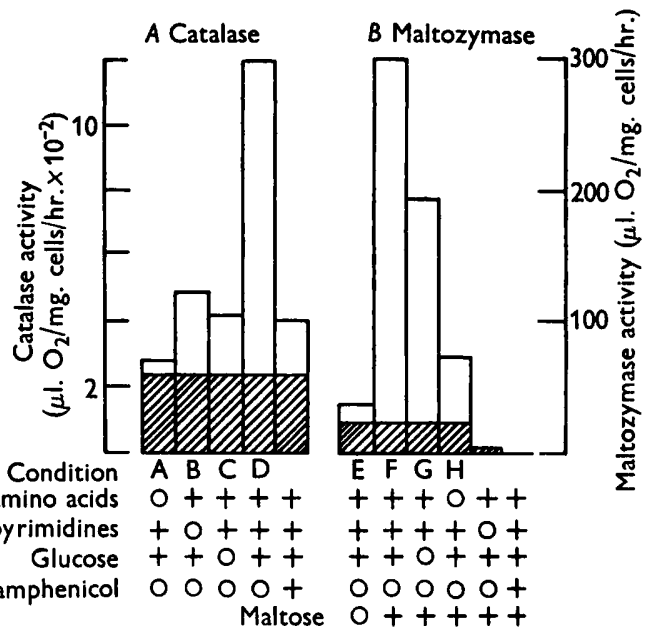

Fig. 6

Fig. 5. Effect of temperature on rate of $\left[{ }^{14} \mathrm{C}\right]$ glycine incorporation into protein fraction. Conditions as for Fig. 2, curve 1, but with incubation temperature as indicated.

Fig. 6. Development of enzymic activities in washed suspensions of Bacillus 631. Incubation medium contained buffered salts, 18 amino acids $(100 \mu \mathrm{g} . / \mathrm{ml}$.$) , purine-pyrimidine$ mixture $(10 \mu \mathrm{g} . / \mathrm{ml}$.$) and glucose (1 \%, \mathrm{w} / \mathrm{v})$ with omissions as shown and addition of maltose $(100 \mu \mathrm{g} . / \mathrm{ml}$.) or chloramphenicol $(50 \mu \mathrm{g} . / \mathrm{ml}$.) where indicated. Enzyme activities determined after incubation for $60 \mathrm{~min}$. at $55^{\circ}$; initial activities indicated by shaded areas.

\section{Development of enzyme activities in washed suspensions}

In a search for inducible enzyme systems in Bacillus 631 the following enzymes (enzyme activities found to be present in organisms grown under normal conditions are italicized) were investigated: tetrathionase, urease, pyrophosphatase, arginine dihydrolase, decarboxylases for a number of amino acids, catalase and $\beta$-galactosidase; and oxidation of lactose, galactose, arabinose, maltose and salicin. The catalase activity of organisms grown under nitrogen 
was the only case in which large increases in activity were induced in washed suspensions. The replacement of glucose by lactose or maltose in the growth medium resulted in approximately a tenfold increase in the oxidative activity towards the relevant substrate of the organisms from these cultures, but only maltozymase showed consistent increases in activity when washed suspensions were incubated with maltose. Optimum conditions for the development of catalase and maltozymase in washed suspensions are shown in Fig. 6; amino acids, purines and pyrimidines, and an energy source are all required for optimum enzyme formation, omission of any of these reducing formation to one-third or less. The development of both enzymes was inhibited by chloramphenicol at approximately ten times the growth-inhibitory concentration, and it seems probable that the development of both activities was due to synthesis of new enzyme protein.

\section{Effect of temperature on rate of development of enzyme activities}

Below $37^{\circ}$ the rate of increase of activity was very low in both cases, and the optimum temperature for enzyme formation appeared to be near to that for growth $\left(c .50^{\circ}\right)$ (Figs. 7, 8). It was clearly higher than that found for tetrathionase synthesis $\left(35^{\circ}-37^{\circ}\right)$ in Salmonella paratyphi $B$ (Pollock, 1945) or penicillinase synthesis $\left(c .37^{\circ}\right)$ in Bacillus cereus (Knox \& Collard, 1952), both of which organisms are considered to be mesophilic.

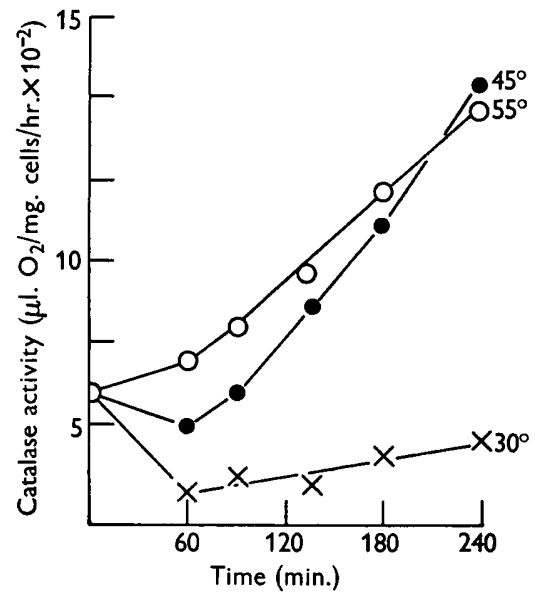

Fig. 7

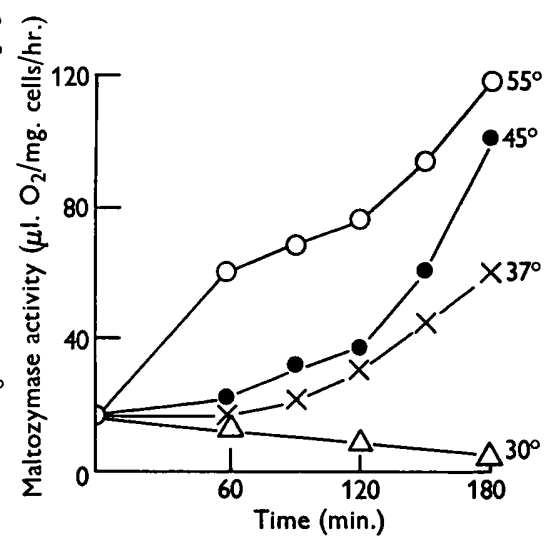

Fig. 8

Fig. 7. Effect of temperature on rate of development of catalase activity. Incubation medium as for Fig. 6, condition $D$, but with incubation temperature as indicated.

Fig. 8. Effect of temperature on rate of development of maltozymase activity. Incubation medium as for Fig. 6, condition F, but with incubation temperature as indicated.

Incubation of organisms at $55^{\circ}$ in buffered salts alone resulted in a decrease in the catalase and $\beta$-galactosidase activities whereas these activities showed, respectively, an increase and little change when incubation took place under condition 2; the addition of $100 \mu \mathrm{g}$. chloramphenicol $/ \mathrm{ml}$. abolished this 
stabilizing effect of condition 2 (Fig. 9A, B). To determine whether the loss of enzyme activity was due to a general autolytic breakdown of protein, organisms were grown in a medium containing a generally $\left[{ }^{14} \mathrm{C}\right]$-labelled protein hydrolysate, and the release of ${ }^{14} \mathrm{C}$ from the protein fraction of organisms incubated in buffered salts alone was followed. No significant release of radioactivity was found. Electron micrographs of organisms after incubation under these conditions show that, whereas in buffer alone most of the organisms lysed and lost electron-dense material, under condition 2 they remained morphologically normal.

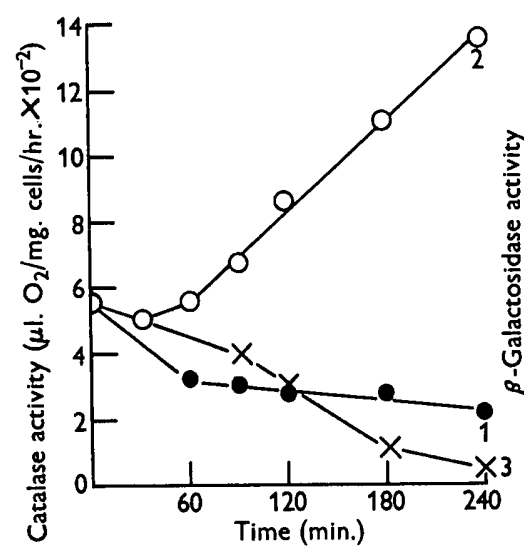

Fig. 9A

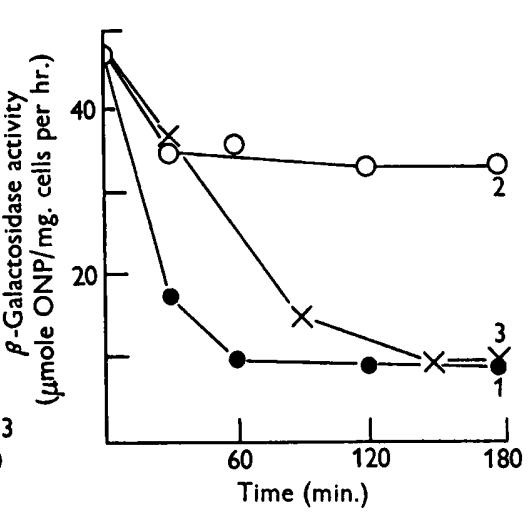

Fig. 9B

Fig. 9. Effect of nature of the incubation medium on loss of catalase and $\beta$-galactosidase activities. Incubation medium contained: curve 1 , buffered salts; curve 2 , as curve 1 with addition of 18 amino acids (100 $\mu \mathrm{g} . / \mathrm{ml}$.), purine-pyrimidine mixture (10 $\mu \mathrm{g} . / \mathrm{ml}$. and glucose $(1 \%, w / v)$; curve 3 , as curve 2 with the addition of chloramphenicol $\left(100 \mu \mathrm{g} . / \mathrm{ml}\right.$.). Incubation temperature $55^{\circ}$. Fig. 9A, catalase activities. Fig. 9B, $\beta$-galactosidase activities.

\section{DISCUSSION}

The system responsible for the incorporation of glycine into the protein of Bacillus 631 shows the same response to the presence of a mixture of 17 other amino acids (condition 2) as does the system which incorporates glutamic acid into the protein of Staphylococcus aureus (Gale \& Folkes, 1953a), and in the presence of these amino acids the linear incorporation is accompanied by protein synthesis. It is possible that incorporation when glycine is the only amino acid present (condition 1) ceases when the amino acids of the internal pool are exhausted and net protein synthesis can no longer occur; the situation is complicated by the fact that in the absence of added amino acids most of the organisms lyse, so that the cessation of incorporation may only reflect loss of activity of the incorporation mechanism when the organisms lyse. Because of the failure to find any reversal of incorporation under condition 1 , it is not possible to conclude that for Bacillus 631 the mechanisms of incorporation under the two conditions are different. 
The requirement for amino acids for the development of enzyme activities, and the effect thereon of chloramphenicol, make it probable that synthesis of new enzyme is occurring under the conditions used. Since the synthesis of certain adaptive enzymes in Staphylococcus aureus requires concomitant synthesis of ribonucleic acid (Creaser, 1955, 1956), and is stimulated by purines and pyrimidines, it seems possible that a similar situation obtains in the case of Bacillus 631 and that this is the basis for the marked stimulation of enzyme formation and of glycine incorporation by added purines and pyrimidines.

The substances necessary for the maintenance of $\beta$-galactosidase activity are the same as those necessary for the synthesis of other enzymes (compare Fig. 6), and since the presence of chloramphenicol under condition 2 results in a loss of enzyme similar to that which occurs in buffer alone it seems a reasonable deduction that the maintenance of $\beta$-galactosidase and the production of catalase are due to synthesis of new enzyme protein which compensates for inactivation. The latter is probably a thermal and not an autolytic process since no loss of radioactivity from the protein fraction was shown.

The experimental results indicate that the protein-synthesizing systems of this thermophilic organism are less thermolabile than those comparable systems which have been studied in mesophilic organisms; nevertheless, it appears that at high temperatures the organism maintains certain enzyme activities by a synthesis which balances thermal inactivation. In this respect the experimental evidence supports the theory put forward by Allen (1953).

The author is indebted to the Medical Research Council for a Scholarship for Training in Research Methods, and to Dr E. F. Gale, F.R.S., and Dr R. Davies for much helpful advice.

\section{REFERENCES}

Adye, J. \& Koffler, H. (1953). Bacterial flagella as test system for studying heat resistance. Bact. Proc. p. 91.

Allen, M. B. (1950). The dynamic nature of thermophily. J. gen. Physiol. 33, 205.

Allen, M. B. (1953). The thermophilic aerobic sporeforming bacteria. Bact. Rev. $17,125$.

Casman, E. P. \& RetTger, L. F. (1933). Limitation of bacterial growth at higher temperatures. J. Bact. 26, 77.

Cocking, E. C. \& Yemm, E. W. (1954). Estimation of amino acids by ninhydrin. Biochem. J. 58, xii.

Creaser, E. H. (1955). The induced (adaptive) biosynthesis of $\beta$-galactosidase in Staphylococcus aureus. J. gen. Microbiol. 12, 288.

Creaser, E. H. (1956). The assimilation of amino acids by bacteria. 22. The effect of 8-azaguanine upon enzyme formation in Staphylococcus aureus. Biochem. J. 64, 539 .

Edward, O. F. \& RETTGER, L. F. (1937). The relation of certain respiratory enzymes to the maximum growth temperature of bacteria. J. Bact. 34, 489 .

GALE, E. F. (1947). The assimilation of amino acids by bacteria. 1. The passage of certain amino acids across the cell wall and their concentration in the internal environment of Streptococcus faecalis. J. gen. Microbiol. $1,53$.

Gale, E. F. \& Folkes, J. P. $(1953 a)$. The assimilation of amino acids by bacteria. 18. The incorporation of glutamic acid into the protein fraction of Staphylococcus aureus. Biochem. J. 55, 721. 
Gale, E. F. \& Folkes, J. P. (1953b). The assimilation of amino acids by bacteria. 19. The inhibition of phenylalanine incorporation in Staphylococcus aureus by chloramphenicol and $p$-chlorophenylalanine. Biochem. J. 55, 730.

Gale, E. F. \& Folkes, J. P. (1955). The assimilation of amino acids by bacteria. 20. The incorporation of labelled amino acids by disrupted staphylococcal cells. Biochem. J. 59, 661.

Johnson, M. J. (1941). Isolation and properties of a pure yeast polypeptidase. J. biol. Chem. 137, 575.

Knox, R. \& Colland, P. (1952). The effect of temperature on the sensitivity of Bacillus cereus to penicillin. J. gen. Microbiol. 6, 369.

LEDERBERG, J. (1950). The $\beta$-D-galactosidase of Escherichia coli strain K12. J. Bact. $60,381$.

Lineweaver, H. \& Burk, D. (1934). The determination of enzyme dissociation constants. J. Amer. chem. Soc. 56, 658.

MARKhaM, R. (1942). A steam distillation apparatus suitable for micro-Kjeldahl analysis. Biochem. J. 36, 790.

Mrlitzer, W. \& Burns, L. (1954). Thermal enzymes. 6. Heat stability of pyruvic oxidase. Arch. Biochem. Biophys. 52, 66.

Militzer, W., Sonderegger, T. B., TutTle, L. C. \& Georgi, C. E. (1950). Thermal enzymes. 2. Cytochromes. Arch. Biochem. 26, 299.

Militzer, W. \& Tutrle, L. C. (1952). Thermal enzymes. 4. Partial separation of an adenosinetriphosphatase from an apyrase fraction. Arch. Biochem. Biophys. 39, 379.

Militzer, W., Tuttle, L. C. \& Georgi, C. E. (1951). Thermal enzymes. 3. Apyrase from a thermophilic bacterium. Arch. Biochem. Biophys. 31, 416.

Pollock, M. R. (1945). The influence of temperature on the adaptation of 'tetrathionase' in washed suspensions of Bact. paratyphosum B. Brit. J. exp. Path. 26, 410.

Roberts, R. B., Abelson, P. H., Cowie, D. B., Bolton, E. B. \& Britten, R. J. (1955). Studies of biosynthesis in Escherichia coli. Publ. Carneg. Instn, no. 607.

Stewart, B. T. (1953). Heat-resistant enzyme from bacterial spores. Fed. Proc. 12, 275. 